\title{
Synthesis of 3-(4-Hydroxy-3-Metoxyphenyil)-1-Phenyl-2-Propen-1-On and its Antioxidant Activity Assay using DPPH
}

\author{
Yuzkiya Azizah, Ahmad Hanapi, Tri Kustono Adi \\ Jurusan Kimia, Fakultas Sains dan Teknologi, Universitas Islam Negeri Maulana Malik Ibrahim Malang \\ Email: ayuzkya@gmail.com
}

\begin{abstract}
3-(4-hydroxy-3-methoxyphenyl)-1-phenylprop-2-en-1-one has been synthezed using aldol condensation reaction from vanillin. The research aims to incrase the potency of vanillin as antioxidant. The synthesis was carried out using reflux method at $70{ }^{\circ} \mathrm{C}$ for 1,5 hours at various moles between vanillin and acetophenone i.e. 1:1; 1:1,5; and 1,5:1. The products were characterized by TLC, FTIR, GC-MS and evaluated for their antioxidant potential using DPPH (2,2-diphenyl-1picrylhydrazyl) assay. The best product was obtained by various moles between vanillin and acetophenone at $1: 1,5$ as a bright yellow solid with a melting point at $65{ }^{\circ} \mathrm{C} ; 76.56 \%$ yield; and 87.02 $\%$ purities, with $\mathrm{IC}_{50}$ of the product is $0.179 \mathrm{mM}$.
\end{abstract}

Keywords: aldol condensation, antioxidant, vanillin

\begin{abstract}
ABSTRAK
3-(4-hidroksi-3-metoksifenil)-1-fenil-2-propen-1-on dapat disintesis melalui reaksi kondensasi aldol dari vanilin. Penelitian ini bertujuan untuk meningkatkan aktivitas antioksidan dari senyawa vanilin. Reaksi kondensasi aldol antara vanilin dengan asetofenon dilakukan menggunakan metode refluks pada suhu $70{ }^{\circ} \mathrm{C}$ selama 1,5 jam dengan variasi mol antara vanilin dan asetofenon sebesar $1: 1 ; 1: 1,5 ;$ dan $1,5: 1$. Senyawa produk yang terbentuk diidentifikasi menggunakan KLT dan dikarakterisasi menggunakan FTIR dan KG-SM. Senyawa produk selanjutnya diuji aktivitas antioksidannya dengan metode DPPH. Hasil penelitian menunjukkan bahwa masing-masing produk hasil sintesis mengandung senyawa target 3-(4-hidroksi-3-metoksifenil)-1-fenil-2propen-1-on. Variasi terbaik didapatkan dari reaksi melalui perbandingan mol (vanilin:asetofenon) 1:1,5 dengan produk berbentuk padatan berwarna kuning, memiliki kemurnian sebesar $87,02 \%$, persen hasil $76,56 \%$, dan nilai $\mathrm{IC}_{50}$ sebesar $0,179 \mathrm{mM}$.
\end{abstract}

Kata Kunci: antioksidan, kondensasi aldol, vanilin

\section{PENDAHULUAN}

Vanilin merupakan senyawa fenol turunan benzena yang memiliki rumus molekul $\mathrm{C}_{8} \mathrm{H}_{8} \mathrm{O}_{3}$ dengan gugus fungsi metoksi $\left(-\mathrm{OCH}_{3}\right)$ pada posisi orto dan gugus aldehida $(-\mathrm{COH})$ pada posisi para. Sarifudin (2002) dalam Budimarwanti (2009) memaparkan bahwa gugus fenol yang terdapat pada senyawa vanilin menjadikan vanilin aktif sebagai senyawa antioksidan dan berpotensi untuk meredam senyawa radikal bebas.
Shyamala dkk., (2007) menyatakan bahwa aktivitas antioksidan senyawa vanilin masih cukup rendah sehingga untuk menetralkan radikal bebas dibutuhkan vanilin dengan konsentrasi yang tinggi. Berdasarkan penelitian tersebut, maka sekiranya perlu dilakukan penelitian untuk menaikkan aktivitas antioksidan dari vanilin.

Salah satu cara yang dapat dilakukan adalah memperpanjang sistem konjugasi dari vanilin. Penelitian Naik et al. (2013) menyatakan bahwa semakin panjang sistem 
konjugasi, maka semakin kecil nilai $\mathrm{IC}_{50}$ suatu senyawa, dengan kata lain semakin besar aktivitas antioksidannya.

Gugus fungsi yang paling mudah bereaksi pada senyawa vanilin adalah gugus aldehida (Kumar et al., 2013). Hal ini dapat dimanfaatkan untuk membentuk senyawa baru melalui reaksi kondensasi aldol.

Vanilin merupakan senyawa fenol dengan gugus aldehid tanpa memiliki atom $\mathrm{H} \alpha$, sehingga untuk membentuk senyawa baru melalui mekanisme kondensasi aldol diperlukan senyawa keton atau aldehida lain yang memiliki atom $\mathrm{H} \alpha$.

Sintesis senyawa organik melalui reaksi kondensasi aldol silang lebih efektif menggunakan katalis basa dibandingkan dengan katalis asam (Budimarwanti dan Handayani, 2010). Keberadaan $\mathrm{NaOH}$ sebagai katalis dalam reaksi kondensasi aldol juga memegang peranan penting. Konsentrasi $\mathrm{NaOH}$ yang tepat akan membantu reaksi kondensasi aldol sehingga reaksi dapat berjalan dengan baik dan produk yang dihasilkan pun akan semakin banyak (Pranowo dkk., 2010).

Madiyono (2002) telah mereaksikan vanilin dan asetofenon menggunakan katalis basa $\mathrm{NaOH} 60 \%$ selama 1,5 jam dengan variasi suhu. Hasil yang diperoleh menyatakan bahwa hasil terbaik reaksi dilakukan pada suhu $70{ }^{\circ} \mathrm{C}$. Gambar 1 menunjukkan reaksi yang terjadi antara vanilin dan asetofenon dengan bantuan katalis basa.

Mengacu pada penelitian Madiyono (2002), maka pada penelitian ini dilakukan sintesis ulang menggunakan variasi mol antara vanilin dan asetofenon sebesar $1: 1 ; 1: 1,5$; dan 1,5:1. Produk hasil sintesis yang diperoleh diidentifikasi menggunakan Kromatografi Lapis Tipis (KLT) dan dianalisis menggunakan Spektrofotometer FTIR (Fourier Transform Infrared Spectrofotometer) dan Kromatografi Gas-Spektrofotometer Massa (KG-SM) untuk mengetahui struktur senyawanya.
Berdasarkan strukturnya, senyawa produk hasil sintesis memiliki gugus $-\mathrm{OH}$ fenolat dan sistem terkonjugasi yang panjang sehingga dimungkinkan memiliki aktivitas antioksidan. Aktivitas antioksidan pada penelitian ini ditentukan dengan menggunakan metode DPPH (2,2-diphenyl-1-picrylhydrazyl). Metode DPPH dipilih karena metode ini merupakan metode yang sangat sederhana, mudah dan cepat dilakukan, serta hanya memerlukan sedikit sampel (Purwaningsih, 2012).

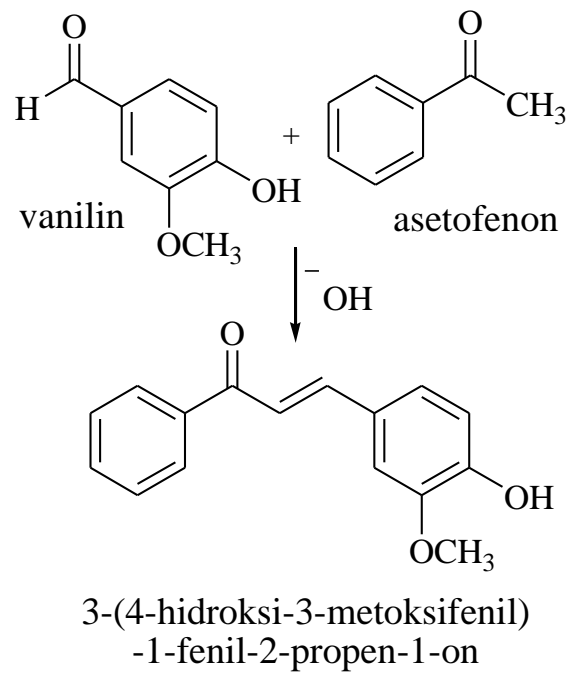

Gambar 1 Reaksi antara vanilin dan asetofenon

\section{METODE PENELITIAN}

\section{Sintesis Senyawa 3-(4-hidroksi-3- metoksifenil)-1-fenil-2-propen-1-on (Madiyono, 2002)}

Sebanyak 2,5 g vanilin $(0,0164 \mathrm{~mol})$ dilarutkan dalam $15 \mathrm{~mL}$ etanol $96 \%$. Dimasukkan larutan ke dalam labu leher tiga yang dilengkapi dengan pendingin, pengaduk magnet, termometer, dan penangas air. Ditambah 1,91 mL $(0,0164 \mathrm{~mol})$ asetofenon dan $10 \mathrm{~mL} \mathrm{NaOH} 60 \%$. Campuran direfluks pada suhu $70{ }^{\circ} \mathrm{C}$ selama 1,5 jam, kemudian didinginkan pada suhu kamar. Campuran kemudian diencerkan dengan akuades secukupnya dan diasamkan dengan $\mathrm{HCl} 10 \%$ hingga $\mathrm{pH}=1$. Padatan yang terbentuk dipisahkan dengan cara dekantasi, kemudian dikeringkan dalam desikator. Setelah kering, 
padatan ditimbang, ditentukan titik lelehnya dengan alat penentu titik leleh dan diidentifikasi senyawa target hasil sintesis menggunakan KLT, kemudian dikarakterisasi menggunakan FTIR dan KG-SM.

Variasi mol vanilin:asetofenon yang digunakan tertera pada Tabel 1.

Tabel 1 Variasi mol vanilin:asetofenon

\begin{tabular}{|cc|c|c|}
\hline $\begin{array}{c}\text { Variasi mol } \\
\text { vanilin:asetofenon }\end{array}$ & $\begin{array}{c}\text { Vanilin } \\
(\mathbf{g})\end{array}$ & $\begin{array}{c}\text { Asetofenon } \\
(\mathbf{m L})\end{array}$ \\
\hline $1,0 \quad: \quad 1,0$ & 2,5 & 1,91 \\
\hline $1,0:: 1,5$ & 2,5 & 2,87 \\
\hline $1,5 \quad: \quad 1,0$ & 3,74 & 1,91 \\
\hline
\end{tabular}

\section{Penentuan Aktivitas Antioksidan Senyawa Metode DPPH (Naik et al., 2013)}

Produk sintesis dilarutkan dalam pelarut etanol dengan konsentrasi 0,$25 ; 0,05 ; 0,1 ; 0,2$; dan $0,5 \mathrm{mM}$. Disiapkan lima tabung reaksi untuk masing-masing konsentrasi. Tiap tabung reaksi diisi dengan $1 \mathrm{~mL}$ larutan sampel dan ditambahkan $4 \mathrm{~mL}$ larutan DPPH 0,1 mM. Setelah itu larutan ditutup dengan alumunium foil dan diinkubasi suhu $37^{\circ} \mathrm{C}$ selama $150-190$ menit. Kemudian diukur absorbansinya menggunakan spektrofotometer UV-Vis pada $516 \mathrm{~nm}$. Data absorbansi yang diperoleh dari tiap konsentrasi dihitung nilai persen (\%) aktivitas antioksidannya. Nilai tersebut diperoleh dengan persamaan:

$$
\underset{\substack{\% \text { A i tivitas } \\ \text { antioksidan }}}{*}=\frac{\text { A kontrol }- \text { A sampel }}{\text { A kontrol }} \times 100 \%
$$

Kontrol yang digunakan adalah $1 \mathrm{~mL}$ etanol dalam $4 \mathrm{~mL}$ larutan DPPH $0,1 \mathrm{mM}$. Setelah

Tabel 3 Hasil sintesis senyawa 3-(4-hidroksi-3-metoksifenil)-1-fenil-2-propen-1-on

\begin{tabular}{|l|c|c|c|}
\hline \multicolumn{1}{|c|}{ Sifat } & $\begin{array}{c}\text { Produk hasil sintesis I } \\
\text { (vanilin:asetofenon } \\
1: 1)\end{array}$ & $\begin{array}{c}\text { Produk hasil sintesis II } \\
\text { (vanilin:asetofenon } \\
1: 1,5)\end{array}$ & $\begin{array}{c}\text { Produk hasil sintesis } \\
\text { III } \\
\text { (vanilin:asetofenon } \\
1,5: 1 \text { ) }\end{array}$ \\
\hline Bentuk & Padatan & Padatan & Padatan \\
\hline Warna & Kuning & Kuning terang & Kuning kecoklatan \\
\hline Titik leleh & $76^{\circ} \mathrm{C}$ & $65^{\circ} \mathrm{C}$ & $72^{\circ} \mathrm{C}$ \\
\hline Berat & $2,2284 \mathrm{~g}$ & $3,6689 \mathrm{~g}$ & $2,1812 \mathrm{~g}$ \\
\hline Kemurnian & $84,91 \%$ & $87,02 \%$ & $68,05 \%$ \\
\hline Persen hasil & $45,37 \%$ & $76,56 \%$ & $35,59 \%$ \\
\hline
\end{tabular}

didapatkan persen aktivitas antioksidan, selanjutnya dihitung nilai $\mathrm{IC}_{50}$ menggunakan persamaan regresi.

Senyawa pembanding berupa vanilin, vitamin $\mathrm{C}$, dan BHT diperlakukan sama seperti sampel akan tetapi larutan sampel yang digunakan diganti dengan larutan vanilin, vitamin C, dan BHT secara bergantian dengan masing-masing konsentrasi seperti tertera pada Tabel 2.

Tabel 2 Konsentrasi senyawa pembanding

\begin{tabular}{|l|c|c|c|c|c|}
\hline \multirow{2}{*}{ Senyawa } & \multicolumn{5}{|c|}{ Konsentrasi } \\
\cline { 2 - 6 } & $\mathbf{K}_{\mathbf{1}}$ & $\mathbf{K}_{\mathbf{2}}$ & $\mathbf{K}_{\mathbf{3}}$ & $\mathbf{K}_{\mathbf{4}}$ & $\mathbf{K}_{\mathbf{5}}$ \\
\hline Vanilin & 0,2 & 0,4 & 0,6 & 0,8 & 1,0 \\
\hline Vitamin C & 0,025 & 0,05 & 0,1 & 0,2 & 0,5 \\
\hline BHT & 0,025 & 0,05 & 0,1 & 0,2 & 0,5 \\
\hline
\end{tabular}

\section{HASIL DAN PEMBAHASAN}

Senyawa 3-(4-hidroksi-3-metoksifenil)1-fenil-2-propen-1-on disintesis dengan cara mereaksikan senyawa vanilin dan asetofenon melalui reaksi kondensasi aldol menggunakan tiga variasi perbandingan mol antara senyawa vanilin dan asetofenon yaitu sebesar (vanilin:asetofenon) $1: 1 ; 1: 1,5 ;$ dan 1,5:1. Larutan basa $\mathrm{NaOH} 60 \%$ digunakan untuk mempercepat laju reaksi kondensasi aldol yang terjadi. Pada penelitian ini, metode refluks digunakan untuk memaksimalkan proses sintesis, yaitu dengan menggunakan suhu pemanasan $70{ }^{\circ} \mathrm{C}$ selama 1,5 jam. Hasil dari masing-masing sintesis senyawa tertera pada Tabel 3 . 


\section{Identifikasi Senyawa Produk Hasil Sintesis Metode KLT}

Produk hasil sintesis yang didapatkan diidentifikasi dengan metode KLT menggunakan kloroform sebagai eluen. Ketiga produk hasil sintesis yang didapatkan dielusi pada satu plat silika $\mathrm{GF}_{254} \quad 10 \times 5 \mathrm{~cm}$ menggunakan vanilin sebagai pembanding. Hasil identifikasi menunjukkan bahwa masingmasing totolan memiliki spot dengan warna dan jarak elusi yang berbeda dengan vanilin, baik ketika di bawah cahaya ruang maupun di bawah sinar UV. Hal ini menunjukkan bahwa reaksi telah terjadi dan senyawa baru telah terbentuk. Warna dan Rf dari masing-masing spot tertera pada Tabel 4.

Tabel 4 Hasil analisis menggunakan KLT

\begin{tabular}{|l|c|c|c|}
\hline \multirow{2}{*}{ Spot } & \multicolumn{2}{|c|}{ Warna } & \multirow{2}{*}{ Rf } \\
\cline { 2 - 3 } & $\begin{array}{c}\text { Cahaya } \\
\text { ruang }\end{array}$ & $\begin{array}{c}\text { Sinar } \\
\text { UV }\end{array}$ & \\
\hline Vanilin $\left(\mathbf{a}_{1}\right)$ & - & Gelap & 0,4375 \\
\hline Produk I $\left(\mathbf{b}_{1}\right)$ & Kuning & Hijau & 0,5625 \\
\hline Produk II $\left(\mathbf{b}_{2}\right)$ & Kuning & Hijau & 0,5375 \\
\hline Produk III (b) $\left.\mathbf{b}_{3}\right)$ & Kuning & Hijau & 0,5625 \\
\hline
\end{tabular}

Tabel 5 Hasil analisis spektra FTIR

\begin{tabular}{|c|c|c|}
\hline \multirow{2}{*}{ Gugus fungsi } & \multicolumn{2}{|c|}{$\begin{array}{c}\text { Bilangan gelombang } \\
\left(\mathbf{c m}^{-1}\right)\end{array}$} \\
\cline { 2 - 3 } & $\begin{array}{c}\text { Senyawa } \\
\text { vanilin }\end{array}$ & $\begin{array}{c}\text { Produk hasil } \\
\text { sintesis }\end{array}$ \\
\hline -OH alkohol & 3180 & 3420 \\
\hline -C-O alkohol & 1200 & 1212 \\
\hline -C-O eter & 1266 & 1273 \\
\hline -Csp'-H & 2946 & 2936 \\
\hline -Csp'-H & 3025 & 3066 \\
\hline $\begin{array}{c}\text {-C=C- } \\
\text { aromatik }\end{array}$ & $1588 ; 1465$ & $1584 ; 1421$ \\
\hline -C=O keton & - & 1654 \\
\hline -C=O aldehida & 1665 & - \\
\hline -C-H aldehida & 2744 & - \\
\hline \multicolumn{2}{|c}{} \\
\hline
\end{tabular}

\section{Karakterisasi dengan Menggunakan Spektrofotometer FTIR}

Karakterisasi senyawa menggunakan FTIR dilakukan untuk mengetahui adanya beberapa gugus fungsi dari senyawa target.
Serapan yang diharapkan muncul pada produk hasil sintesis adalah keton $(-\mathrm{C}=\mathrm{O})$; metoksi ($\left.\mathrm{O}-\mathrm{CH}_{3}\right)$; dan alkohol (-OH).

Hasil analisis menunjukkan bahwa perbedaan spektra terletak pada adanya gugus aldehida yang terlihat pada spektra vanilin dan gugus keton terlihat pada spektra produk hasil sintesis. Tabel 4.3 merupakan tabel hasil analisis spektra FTIR senyawa vanilin dan produk hasil sintesis.

\section{Karakterisasi Menggunakan KG-SM}

Karakterisasi senyawa produk hasil sintesis menggunakan KG-SM dilakukan untuk memastikan adanya senyawa target pada produk hasil sintesis. Banyaknya puncak yang muncul pada kromatogram menunjukkan jumlah senyawa yang terkandung pada produk hasil sintesis. Puncak kromatogram yang didapatkan disertai dengan persen areanya dalam satuan persen (\%) dan perkiraan senyawanya berdasarkan nilai $\mathrm{m} / \mathrm{z}$.

Hasil analisis ketiga kromatogram menyatakan bahwa masing-masing produk hasil sintesis mengandung senyawa target 3-(4hidroksi-3-metoksifenil)-1-fenil-2-propen-1-on. Data kemurnian serta persen hasil senyawa target pada masing-masing kromatogram tertera pada Tabel 6.

Tabel 6 Hasil analisis KG-SM

\begin{tabular}{|c|c|c|}
\hline Kromatogram & Kemurnian & $\begin{array}{c}\text { Persen } \\
\text { hasil }\end{array}$ \\
\hline Pertama & $84,91 \%$ & $45,37 \%$ \\
\hline Kedua & $87,02 \%$ & $76,56 \%$ \\
\hline Ketiga & $68,05 \%$ & $35,59 \%$ \\
\hline
\end{tabular}

Berdasarkan Tabel 6 diketahui bahwa hasil reaksi terbaik didapatkan melalui perbandingan mol vanilin:asetofenon 1:1,5.

\section{Penentuan Aktivitas Antioksidan Produk Hasil Sintesis}

Penentuan aktivitas antioksidan dilakukan melalui pembacaan absorbansi dari spektrofotometer UV-Vis pada panjang 
gelombang $516 \mathrm{~nm}$. Absorbansi yang terbaca merupakan nilai absorbansi DPPH sisa yang tidak mampu dinetralkan menjadi DPPH-H. Semakin kecil DPPH yang tersisa, maka semakin tinggi aktivitas antioksidan dari senyawa. Tabel 7 menunjukkan nilai aktivitas antioksidan produk hasil sintesis dan pembanding dalam satuan persen (\%).
Tabel 7 menunjukkan bahwa persentase aktivitas antioksidan senyawa produk memiliki nilai yang lebih rendah dibandingkan dengan vitamin $\mathrm{C}$ dan BHT. Meski demikian, aktivitas antioksidan senyawa produk hasil sintesis memiliki nilai lebih tinggi dibandingkan dengan senyawa vanilin.

Tabel 7 Nilai Aktivitas antioksidan produk hasil sintesis dan pembanding

\begin{tabular}{|c|c|c|c|c|c|}
\hline \multirow{2}{*}{$\begin{array}{c}\text { Konsentrasi } \\
(\mathbf{m M})\end{array}$} & \multicolumn{3}{|c|}{ \% Aktivitas } & \multirow{2}{*}{ Konsentrasi } & \% Aktivitas \\
\cline { 2 - 3 } \cline { 6 - 6 } & \multirow{2}{*}{ Produk } & $\begin{array}{c}\text { Vitamin } \\
\mathbf{C}\end{array}$ & \multirow{2}{*}{ BHT } & & \multirow{2}{*}{$\begin{array}{c}\text { Vanilin } \\
\end{array}$} \\
\hline $\mathbf{0 , 0 2 5}$ & 4,02 & 18,91 & 10,15 & $\mathbf{0 , 2}$ & 0,80 \\
\hline $\mathbf{0 , 0 5}$ & 10,16 & 34,86 & 22.71 & $\mathbf{0 , 4}$ & 2,67 \\
\hline $\mathbf{0 , 1}$ & 32,35 & 68,53 & 41,24 & $\mathbf{0 , 6}$ & 2,69 \\
\hline $\mathbf{0 , 2}$ & 53,90 & 92,53 & 67,38 & $\mathbf{0 , 8}$ & 3,52 \\
\hline $\mathbf{0 , 5}$ & 81,31 & 97,47 & 81,35 & $\mathbf{1}$ & 3,89 \\
\hline
\end{tabular}

Data pada Tabel 7 selanjutnya digunakan untuk menentukan nilai $\mathrm{IC}_{50}$ masing-masing senyawa menggunakan persamaan regresi yang menyatakan hubungan antara log konsentrasi sampel (x) dengan persentase aktivitas antioksidan senyawa $(\mathrm{y})$.

Nilai $\mathrm{IC}_{50}$ merupakan nilai yang menyatakan besar konsentrasi senyawa antioksidan untuk meredam $50 \%$ senyawa radikal bebas. Semakin kecil nilai $\mathrm{IC}_{50}$ suatu senyawa, maka semakin tinggi aktivitas antioksidannya. Tabel 8 menunjukkan nilai $\mathrm{IC}_{50}$ senyawa produk dan pembanding dalam satuan $\mathrm{mM}$.

Tabel 8 Nilai IC $_{50}$ produk hasil sintesis dan pembanding

\begin{tabular}{|c|c|c|}
\hline No. & Senyawa & Nilai $\mathbf{I C}_{\mathbf{5 0}}(\mathbf{m M})$ \\
\hline 1. & Produk & 0,179 \\
\hline 2. & Vanilin & 14,053 \\
\hline 3. & Vitamin C & 0,065 \\
\hline 4. & BHT & 0,128 \\
\hline
\end{tabular}

Berdasarkan Tabel 7 dan Tabel 8 maka dapat dinyatakan bahwa kekuatan antioksidan senyawa secara berturut-turut adalah vitamin $\mathrm{C}$, BHT, produk hasil sintesis, dan vanilin.

\section{KESIMPULAN}

1. Produk hasil reaksi kondensasi aldol antara vanilin dan asetofenon adalah senyawa 3-(4hidroksi-3-metoksifenil)-1-fenil-2-propen-1on dalam bentuk padatan. Warna dari produk hasil sintesis ketiga variasi mol antara vanilin dan asetofenon $1: 1 ; 1,5: 1$; 1:1,5 secara berurutan adalah kuning; kuning terang; dan kuning kecoklatan dengan titik leleh sebesar $76{ }^{\circ} \mathrm{C} ; 65^{\circ} \mathrm{C}$; dan $72{ }^{\circ} \mathrm{C}$, serta persen hasil sebesar $45,37 \%$; $76,56 \%$; dan $35,59 \%$.

2. Produk hasil sintesis memiliki aktivitas antioksidan dengan nilai $\mathrm{IC}_{50}$ sebesar 0,179 $\mathrm{mM}$ melalui metode DPPH.

\section{DAFTAR PUSTAKA}

Budimarwanti, C. 2009. Sintesis Senyawa 4Hidroksi -5-Dimetilaminometil-3Metoksibenzil Alkohol dengan Bahan Dasar Vanilin Melalui Reaksi Mannich. UNY, Yogyakarta.

Budimarwanti, C dan Handayani, S. 2010. Efektivitas Katalis Asam Basa pada Sintesis 2-hidroksikalkon, Senyawa yang Berpotensi sebagai Zat Warna. Prosiding seminar nasional Kimia dan Pendidikan Kimia 2010. ISBN: 978-979-98117-7-6. 
Handayani, S., Arianingrum, R., dan Haryadi, W. 2011. Vanillin Structure Modification of Isolated Vanilla Fruit (Vanilla planifolia Andrews) to form Vanillinacetone. Proceedings at $14^{\text {th }}$ Chemical Congress 2011. Page 252-257.

Madiyono, M. 2002. Sintesis Senyawa 3Metoksi-4-Hidroksikalkon dari Vanilin dan Asetofenon. FMIPA UNDIP, Semarang.

Naik, N., Kumar, V. H., Dias, S. M., and Swami, R. J. 2013. Novel 4-Methoxy-2Acetyl Benzofuran Based Chalcones: A New Perceptivity Into Their Antioxidant Potentials. International Journal of Pharmacy and Pharmaceutical Sciences. Vol 5, Issue 1, page $242-247$.
Pranowo, D., Affandi, M. Y., Candraningrum, W., dan Muchalal, M. 2010. Mempelajari Sintesis 4-(hidroksifenil)-3buten-2-on. Jurusan Kimia Fakultas Matematika dan Ilmu Pengetahuan Alam, Universitas Gadjah Mada, Yogyakarta.

Purwaningsih, S. 2012. ILMU KELAUTAN. Aktivitas Antioksidan dan Komposisi Kimia Keong Matah Merah (Cerithidea obtusa). ISSN 0853-7291. Vol. 17 (1) 39-48. Institut Pertanian Bogor, Bogor.

Shyamala, B. N., Naidu, M., Sulochanamma, G. S., dan Srivinas, P. 2007. Studies on the antioxidant activities of natural vanilla extract and its constituent compounds through in vitro models. Journal of Agricultural and Food Chemistry (55) 7738-7743. 